\title{
Prinsip-prinsip Pendokumentasian Dalam Keperawatan
}

\author{
Try Ayu Amanda Pasaribu
}

\author{
tryayuamanda08@gmail.com
}

\section{LATAR BELAKANG}

Keperawatan merupakan komponen utama dalam sistem pelayanan kesehatan, dan perawat merupakan kelompok pekerja yang paling besar dalam sistem tersebut. Perawat merupakan sumber daya manusia terpenting di rumah sakit karena selain jumlahnya yang dominan (55\%-60\%) juga merupakan profesi yang memberikan pelayanan yang konstan dan terus-menerus 24 jam kepada pasien setiap hari.

Dokumentasi keperawatan adalah setiap catatan baik tertulis maupun elektronik yang menggambarkan layanan keperawatan yang diberikan kepada klien dan dapat digunakan sebagai bukti bagi tenaga yang berwenang.Dokumentasi keperawatan yang sejak awal merupakan pencatatan dalam format kertas (paperbased) dapat dikembangkan menjadi electronicbaseddengan dukungan teknologi informasi dan sistem komputerisasi. Proses dokumentasi keperawatan mencakup pengkajian, identifikasi masalah, perencanaan, dan tindakan. Perawat kemudian mengobservasi dan mengevaluasi respon klien terhadap tindakan yang diberikan, dan mengkomunikasikan informasi tersebut kepada tenaga kesehatan lainnya. Tujuan pendokumentasian asuhan keperawatan adalah untuk memudahkan menentukan kualitas perawat, klien dan memudahkan konsistensi antar disiplin dengan mengkomunikasikan tujuan tindakan dan kemajuan. Pendokumentasian umumnya kurang disukai oleh perawat karena dianggap terlalu rumit, beragam, dan menyita waktu, namun dokumentasi keperawatan yang tidak dilakukan dengan tepat, lengkap dan akurat dapat menurunkan mutu pelayanan keperawatan karena tidak dapat mengidentifikasi sejauh mana tingkat keberhasilan Asuhan Keperawatan yang telah diberikan. Peraturan Pemerintah No.32 Tahun 1996 tentang tenaga kesehatan dan undang-undang No.36 Tahun 2009 merupakan wujud rambu-rambu atas hak dan kewajiban tenaga kesehatan termasuk para perawat dalam menjalankan tugas tugas pelayanan. Dokumentasi keperawatan dalam bentuk dokumen asuhan keperawatan merupakan salah satu alat pembuktian dalam menjalankan tugas keperawatan.

Kualitas dokumentasi asuhan keperawatan secara global masih rendah. Dokumentasi asuhan keperawatan berperan penting dalam praktik keperawatan. Rendahnya kualitas 
pendokumentasian asuhan keperawatan disebabkan oleh berbagai faktor seperti faktor internal yang terdiri dari umur, jenis kelamin, pendidikan dan masa kerja serta faktor eksternal yang terdiri dari pengetahuan, beban kerja dan pemanfaatan teknologi informasi. Rendahnya kelengkapan dokumen asuhan keperawatan tentunya akan berdampak negatif terhadap mutu pelayanan kesehatan secara keseluruhan dan mengakibatkan menurunnya kepuasan pasien terhadap pelayanan keperawatan. Tujuan pendokumentasian asuhan keperawatan adalah sebagai alat komunikasi antara klien, keluarga, tim perawat dan tim kesehatan lain sehingga terbentuk komunikasi yang baik dalam perawatan klien, sebagai tanggung jawab dan tanggung gugat perlindungan klien dalam pelayanan dan keamanan perawat dalam memberikan asuhan keperawatan, sebagai informasi statistik asuhan perencanaan kebutuhan sarana prasarana dan sumber daya manusia di masa mendatang, sebagai sarana pendidikan yang dapat dijadikan media belajar bagi mahasiswa dan bahan penelitian dalam pengembangan ilmu keperawatan, sebagai sumber data dalam audit keperawatan untuk alat ukur dalam penilaian kinerja perawatan, sebagai dokumen yang bisa dijadikan aspek legal dan bukti autentik bagi perawat ketika menghadapi masalah hukum, sebagai jaminan kualitas pelayanan kesehatan dan pelayanan keperawatan. Dokumentasi dalam keperawatan memegang peranan penting terhadap segala macam tuntutan masyarakat yang semakin kritis dan mempengaruhi kesadaran masyarakat akan hak-haknya dari suatu unit kesehatan. pendokumentasian yang tidak dilakukan dengan lengkap dapat menurunkan mutu pelayanan keperawatan karena tidak dapat mengidentifikasi sejauh mana tingkat keberhasilan Asuhan Keperawatan yang telah diberikan.

\section{METODE}

Metode yang digunakan pada kajian ini adalah dengan menganalisis dari berbagai sumber bacaan. Referensi yang saya ambil dari jurnal online, skripsi, dengan pengerjaannya dengan cara membandingkan artikel satu dengan artikel yang lain.

Metode yang digunakan pengkajian ini dengan mengumpulkan informasi dari berbagai referensi termasuk didalamnya hasil-hasil penelitian.

\section{HASIL}

Hasildaripengkajianini adalah Dokumentasi keperawatan merupakan suatu dokumen yang berisi data yang lengkap, nyata, dan tercatat yang memuat seluruh data dari proses keperawatan, meliputi pengkajian, perumusan diagnosis, perencanaan, implementasi, dan evaluasi keperawatan yang disusun secara sistematis, valid, dan dapat dipertanggungjawabkan secara moral dan hukum. Keperawatan merupakan komponen utama dalam sistem pelayanan 
kesehatan, dan perawat merupakan kelompok pekerja yang paling besar dalam sistem tertentu. Sistem pelayanan kesehatan utama adalah suatu sistem dimana pelayanan kesehatan esensial dapat diperoleh dengan mudah secara universal sebagai individu dan keluarga dalam komunitas tertentu, yang disediakan bagi mereka melalui partisipasi penuh dari mereka sendiri, dan dilaksanakan dengan biaya yang dapat terjangkau oleh masyarakat dan pemerintah daerah.

\section{- Prinsip-prinsip Dokumen Asuhan Keperawatan}

Hal pokok dalam prinsip-prinsip dokumen menurut Nursalam (2008) adalah :

1) Dokumen asuhan keperawatan harus dilaksanakan segera setelah pengkajian pertama dilakukan, demikian juga pada setiap langkah kegiatan perawatan.

2) Bila memungkinkan, catat setiap respon pasien atau keluarga.

3) Pastikan kebenaran setiap data yang dicatat dalam dokumen asuhan keperawatan.

4) Data pasien harus objektif dan bukan penafsiran perawat,dalam hal ini perawat mencatat Apa yang dilihat dari respon pasien pada saat merawat pasien mulai dari pengkajian sampai evaluasi.

5) Dokumentasikan Asuhan Keperawatan dengan baik, apabila terjadi hal-hal sebagai berikut : adanya perubahan kondisi atau munculnya masalah baru, respon pasien terhadap bimbingan perawat.

6) Penulisan istilah yang tidak jelas dari setiap catatan yang dibuat harus dihindari. Istilah yang digunakan harus disepakati atas kebijaksanaan institusi setempat.

7) Dokumen yang baku harus dihindari, sebab sifat individu atau klien adalah unik, selain itu setiap pasien mempunyai respon yang berbeda.

8) Data harus ditulis dengan jelas menggunakan tinta, dan jangan menggunakan pensil agar tidak mudah dihapus.

9) Tidak dibenarkan untuk mengubah isi dokumen untuk menutupi kesalahan. Apabila terjadi kesalahan dalam penulisan dapat dicoret dan segera diganti dengan yang benar, kemudian ditandatangani.

10) Untuk setiap kegiatan dokumen, cantumkan waktu, tanda tangan dan nama jelas yang melaksanakan dokumentasi.

11) Wajib membaca setiap tulisan dari anggota tim kesehatan yang lain sebelum menulis data terakhir.

12) Dokumen harus dibuat dengan jelas dan lengkap. 
Pelaksanaan pendokumentasian asuhan keperawatan juga dipengaruhi oleh manajemen waktu perawat yang merupakan proses untuk menyusun dan mencapai tujuan, memperkirakan waktu dan sumber-sumber waktu yang dibutuhkan untuk mencapai masing-masing tujuan dan mendisiplinkan diri sendiri.dokumentasi asuhan keperawatan menggunakan pendekatan proses keperawatan yang terdiri dari pengkajian, perumusan diagnosa, perencanaan, pelaksanaan, dan evaluasi sebagai metode ilmiah penyelesaian masalah keperawatan pada pasien untuk meningkatkan outcomepasien. Ciri dokumentasi Asuhan Keperawatan yang baik adalah berdasarkan fakta (factual basis), akurat (accuracy), lengkap (completeness), ringkas (conciseness), terorganisir (organization), waktu yang tepat (timeliness), dan bersifat mudah dibaca (legability). prinsip prinsip pendokumentasian direvisi menjadi tiga bentuk standar dokumentasi yaitu communication, accountability, dan safety.

Menurut Nursalam (2008) hakikat dokumentasi asuhan keperawatan adalah terciptanya kegiatan-kegiatan keperawatan yang menjamin tumbuhnya pandangan, sikap, cara berpikir, dan bertindak profesional pada setiap perawat. Pendekatan yang sistematis dan logis dengan landasan ilmiah yang benar, serta melalui dokumentasi proses keperawatan, semua kegiatan dalam proses keperawatan dapat ditampilkan kembali sehingga dapat diteliti ulang untuk dikembangkan atau diperbaiki.

Faktor-faktor yang mempengaruhi pendokumentasian asuhan keperawatan

1. Pengetahuan

2. Sikap perawat

3. Penghargaan dari pimpinan

4. Kebijakan

5. Lama bekerja

6. Beban kerja perawat

7. Sarana dan prasarana

Pentingnya pendokumentasian asuhan keperawatan terhadap perlindungan hukum bagi perawat, pencatatan dokumentasi keperawatan menjadi suatu kewajiban yang harus dilakukan oleh perawat. kewajiban untuk melakukan dokumentasi keperawatan ini telah tertera pada Keputusan Menteri Kesehatan Republik Indonesia Nomor HK.02.02/MENKES/148/I/2010, pasal 12 ayat 1 (f), tentang izin dan penyelenggaraan praktik perawat yang menyatakan bahwa perawat berkewajiban untuk melakukan catatan keperawatan secara sistematis.

\section{PEMBAHASAN}


Dokumen keperawatan merupakan catatan yang penting bagi asuhan keperawatan pasien di rumah sakit. dokumen asuhan keperawatan merupakan bukti dari pelaksanaan keperawatan yang menggambarkan pendekatan proses keperawatan dan catatan tentang respon pasien terhadap tindakan medis, tindakan keperawatan atau reaksi pasien terhadap penyakit.Dokumentasi adalah segala yang tertulis atau tercetak oleh individu yang berwewenang. Catatan harus menjelaskan keperawatan yang diberikan kepada klien, status dan kebutuhan klien yang komprehensif. dokumentasi adalah informasi yang tertulis tentang status perkembangan kondisi kesehatan pasien serta semua kegiatan Asuhan Keperawatan yang dilakukan oleh perawat.

Standar dokumentasi adalah suatu pelayanan tentang kualitas dokumentasi yang dipertimbangkan secara adekuat dalam suatu situasi tertentu. Dengan adanya standar bawah adanya suatu ukuran terhadap kualitas dokumentasi keperawatan. Perawat memerlukan suatu standar dokumentasi untuk memperkuat pola pencatatan dan sebagai petunjuk atau pedoman praktis pendokumentasian dalam memberikan tindakan keperawatan. Dalam melaksanakan dokumentasi asuhan keperawatan harus mengikuti 7 Standar Dokumentasi Asuhan Keperawatan yaitu harus sabar, harus berisi pekerjaan yang sebenarnya dari perawat pendidikan dan dukungan psikososial, ditulis harus mencerminkan klinis perawat, harus logis dan berurutan, harus ditulis conteemporameously, catatan harus lengkap tentang keperawatan dan tentang hal diluar keperawatan, harus memenuhi persyaratan hukum.

\section{- Tahap-tahap Pendokumentasian Asuhan Keperawatan}

Dalam pelaksanaan dokumentasi asuhan keperawatan, perawat harus mengikuti beberapa tahapan dokumentasi asuhan keperawatan. Asuhan keperawatan merupakan proses atau rangkaian kegiatan pada praktik keperawatan yang diberikan secara langsung kepada klien berdasarkan kaidah-kaidah keperawatan sebagai suatu profesi yang berdasarkan ilmu dan kiat keperawatan, bersifat humanistik, dan berdasarkan pada kebutuhan objektif klien untuk mengatasi masalah yang dihadapi klien.

\section{- Prinsip-prinsip Pendokumentasian Asuhan Keperawatan}

Prinsip-prinsip yang harus diperhatikan dalam pendokumentasian asuhan keperawatan antara lain dokumentasi harus dilakukan segera setelah pengkajian pertama dilakukan atau pada tiap langkah asuhan keperawatan, catat setiap respon pasien keluarga tentang informasi atau data yang penting, pastikan kebenaran setiap data-data yang akan dicatat, data harus objektif bukan data penafsiran perawat, dokumentasikan bila terjadi perubahan 
kondisi atau timbul masalah baru, hindarkan dokumentasi yang baku karena setiap pasien mempunyai masalah yang berbeda, hindari penggunaan istilah penulisan yang tidak jelas dalam pencatatan harus disepakati dan atas kebijakan institusi, data harus ditulis dengan tinta bukan pensil agar tidak mudah dihapus, bila terjadi kesalahan dalam penulisan dicoret dan ganti dengan yang benar kemudian ditandatangani, setiap dokumentasi cantumkan waktu, tanda tangan, nama jelas penulis, wajib membaca setiap tulisan dari anggota kesehatan lain sebelum menulis, dokumentasi harus dibuat dengan tepat, jelas dan lengkap.

Pengkajian adalah tahap awal dari proses keperawatan dan merupakan proses suatu pengumpulan data yang sistematis dari berbagai sumber untuk mengevaluasi dan mengidentifikasi status kesehatan klien. Menurut Nursalam (2011), kriteria pengkajian keperawatan meliputi :

\section{Tipe data}

Tipe data pada pengkajian keperawatan terdiri data subjektif dan data objektif. data subjektif adalah data yang didapatkan dari klien atau pasien sebagai suatu pendapat terhadap suatu situasi dan kejadian, sedangkan data objektif adalah data yang di observasi dan diukur oleh perawat.

\section{Fokus pengambilan data}

Fokus pengambilan data meliputi riwayat status kesehatan sebelumnya dan saat ini, pola koping yang pernah digunakan dan yang saat ini digunakan, fungsi, status sebelumnya dan saat ini, respon terhadap terapi medis dan intervensi keperawatan, resiko untuk masalah potensial hal-hal yang dapat menjadi dorongan atau kekuatan bagi klien.

\section{Karakteristik data}

Data yang dikumpulkan untuk menunjang diagnosa keperawatan harus mempunyai karakteristik yang lengkap, akurat, nyata dan relevan.

\section{Sumber data}

Data-data yang dikumpulkan dapat diperoleh tidak hanya dari klien tetapi dari orang terdekat (keluarga), catatan klien, riwayat penyakit terdahulu, konsultasi dengan terapi, hasil pemeriksaan diagnostik, catatan medis, dan sumber kepustakaan.

Persepsiperawatberagamtentang prinsip prinsip pendokumentasian mencangkup prinsip kelengkapan, keakuratan, ketepatan waktu, organisasi, aspek legal dokumentasi.Dari 5 prinsip 
tersebut, 4 prinsip telah dipersepsikan dengan baik, kecuali prinsip ketepatan waktu.Perawat mempunyai persepsi yang buruk tentang ketepatan waktu.Perawat seharusnya melakukan dokumentasi tepat waktu untuk menghindari kesalahan.Perawat mencatat semua tindakan tepat waktu, mencatat prosedur, tindakan dan pengkajian segera setelah dilakukan.

Kelengkapanpengisiandokumentasikeperawatan disebabkan oleh berbagai faktor.Beban kerja, banyak macam dokumentasi, bahasa dokumentasi yang tidak dipahami, kurang memahami atau pengetahuan dokumentasi, dan kebijakan lembaga, sumber yang tidak memadai dan budaya rumah Rumah Sakit sebagai dampak dokumentasi perawat.Faktor dominan mempengaruhi kelengkapan dokumentasi keperawatan yaitu pelatihan dan beban kerja.

Pendokumentasian yang tidaklengkap dapat mempengaruhi nilai atau manfaat dari dokumen tersebut seperti berkurangnya nilai hukum, jaminan mutu pelayanan, hilangnya media komunikasi antar teman sejawat atau antar profesi, nilai administratif (keuangan), nilai pendidikan, nilai penelitian dan nilai akreditasi rumah sakit. kinerja perawat dalam pendokumentasian proses keperawatan adalah catatan keluaran hasil dari seluruh aktivitas kerja perawat yang merupakan bukti dari pelaksanaan asuhan keperawatan di rumah sakit dengan menggunakan metode keperawatan. dokumentasi proses asuhan keperawatan merupakan tampilan perilaku atau kinerja perawat pelaksana dalam memberikan proses asuhan keperawatan kepada pasien selama pasien dirawat di rumah sakit. Dokumentasi proses Asuhan Keperawatan yang baik dan berkualitas haruslah akurat, lengkapdansesuaistandar.

\section{Dibawahiniadatahapan dokumentasi asuhan keperawatan yaitu :}

\section{DokumentasiPengkajianAsuhanKeperawatan}

Pengkajianadalahkegiatanuntuk data atau informasi tentang pasien yang diperoleh dari hasil observasi, wawancara, konsultasi, dan pemeriksaan agar dapat mengidentifikasi, mengenali masalah, mengenali kebutuhan kesehatan dan keperawatan pasien baik fisik, sosial dan spiritual. Kriteria pengkajian keperawatan, meliputi pengumpulan data dilakukan dengan cara anamnesis, observasi, pemeriksaan fisik, serta dari pemeriksaan penunjang. Sumber data adalah klien, keluarga atau orang yang terkait, tim kesehatan, rekam medis, dan catatan lain.

\section{Dokumentasi Diagnosa Asuhan Keperawatan}


Tahap diagnosa ini adalah tahap pengambilan keputusan pada proses keperawatan, yang meliputi identifikasi apakah masalah klien dapat dihilangkan, dikurangi atau dirubah masalahnya melalui tindakan keperawatan. Diagnosakeperawatanadalahsuatu pernyataan yang menguraikan respon aktual atau potensial klien terhadap masalah kesehatan yang dapat diatasi oleh kompetensi perawat. Respon aktual dan potensial klien didapatkan dari data dasar pengkajian, tinjauan literatur yang berkaitan, catatan medis masa lalu, dan konsultasi dari profesional yang lain yang membutuhkan intervensi dari domain praktik keperawatan. Perumusan diagnosa keperawatan aktual adalah menjelaskan masalah nyata saat ini sesuai dengan data klinik yang ditemukan. Potensial atau resiko menjelaskan masalah kesehatan nyata akan terjadi jika tidak dilakukan intervensi. Perawat menganalisis data pengkajian untuk merumuskan diagnosis keperawatan meliputi analisis dan interpretasi data, pengumpulan data, identifikasi masalah klien, dan perumusan diagnosis keperawatan.Untuk mengidentifikasi kebutuhan klien, perawat harus menentukan masalah kesehatan klien.Perumusan diagnosa keperawatan didasarkan pada identifikasi kebutuhan klien.Data pengkajian dapat menunjukkan masalah, perawat diarahkan pada pemilihan diagnosa keperawatan yang sesuai.

\section{Dokumentasi Rencana Asuhan Keperawatan}

Selanjutnyaperawatmerumuskantujuan dan hasil yang diperkirakan dengan krayon untuk setiap diagnosa keperawatan yang bertujuan untuk memberikan arahan terhadap intervensi keperawatan dan untuk menentukan keefektifan intervensi keperawatan. Rencana keperawatan adalah semua tindakan yang akan dilakukan oleh perawat untuk membantu klien beralih dari status kesehatan saat ini ke status kesehatan yang lebih baik, diuraikan dalam hasil yang diharapkan. Merupakan pedoman tertulis untuk perawatan klien.Rencana keperawatan terorganisasi sehingga setiap perawat dapat dengan cepat mengidentifikasi tindakan perawatan yang diberikan.RencanaAsuhan Keperawatan yang dirumuskan dengan tepat memfasilitasi kontinuitas asuhan keperawatan dari satu perawat ke perawat lainnya.sebagai hasil semua perawat mempunyai kesempatan untuk memberikan asuhan yang berkualitas tinggi dan konsisten.

\section{Dokumentasi Pelaksanaan (implementasi) Asuhan Keperawatan}

Implementasikeperawatanmerupakaninisiatif dari rencana tindakan untuk mencapai tujuan yang spesifik.Tahap pelaksanaan dimulai setelah rencana tindakan disusun dan ditujukan untuk membantu klien mencapai tujuan yang diharapkan.Rencana tindakan yang spesifik dilakukan untuk memodifikasi faktor-faktor yang mempengaruhi masalah kesehatan klien.Tindakan 
keperawatan dilaksanakan dalam beberapa tahap yaitu pertama tahap persiapan, tahap awal tindakan keperawatan ini menuntut perawat untuk mengevaluasi yang diidentifikasi pada tahap perencanaan.Tahap kedua adalah intervensi yaitu fokus tahap pelaksanaan tindakan perawatan dari perencanaan untuk memenuhi kebutuhan fisik dan emosional. Tahap ketiga adalah dokumentasi pelaksanaan tindakan keperawatan harus diikuti oleh pencatatan yang lengkap dan akurat terhadap suatu kejadian dalam proses keperawatan.

\section{Dokumentasi Evaluasi Asuhan Keperawatan}

Tahapselanjutnyaadalahevaluasi. Perencanaan evaluasi membuat kriteria keberhasilan proses dan keberhasilan tindakan keperawatan. Keberhasilan proses dapat dilihat dengan jalan membandingkan antara proses dengan pedoman atau rencana proses tersebut. Sasaran evaluasi adalah proses asuhan keperawatan berdasarkan kriteria rencana yang telah disusun, hasil tindakan keperawatan berdasarkan kriteria keberhasilan yang telah dirumuskan dalam rencana evaluasi dan hasil evaluasi. Evaluasi dalam dokumentasi asuhan keperawatan di antaranya adalah evaluasi formatif, yaitu evaluasi yang merupakan hasil observasi dan analisa perawat terhadap respon klien segera pada saat dan setelah intervensi keperawatan dilaksanakan, evaluasi ini dapat dilakukan secara spontan dan memberi kesan apa yang terjadi saat itu dan evaluasi sumatif adalah evaluasi yang merupakan rekapitulasi dan kesimpulan dari observasi dan analisis status kesehatan klien sesuai dengan kerangka waktu yang telah ditetapkan pada tujuan keperawatan.

\section{PENUTUP}

Pendokumentasianbagiperawatberguna untuk mengkomunikasikan hal-hal yang telah dilakukan dalam bentuk tulisan, fakta fakta penting tentang pasien dengan tujuan mempertahankan kelangsungan pelayanan kesehatan selama kurun waktu tertentu.Dokumentasi asuhan keperawatan merupakan amanah bagi perawat. Program asuhan keperawatan supaya berjalan secara optimal maka diperlukan pendokumentasian yang lengkap dari tiap-tiap kegiatan sehingga masing-masing kegiatan tetap berhubungan dan membentuk suatu proses yang dinamis dan berkesinambungan. Pendokumentasian juga merupakan catatan kebutuhan pasien, sebagai alat bantu dalam mengidentifikasi masalah, merencanakan tindakan, melaksanakan kegiatan dan mengevaluasi kegiatan yang telah diberikan. Kualitaspendokumentasian keperawatan yang baik akan sangat membantu perawat dalam pengambilan keputusan yang tepat dalam pemberian asuhan keperawatan pasien di rumah sakit. Maka pendokumentasian keperawatan harus berisi data yang sesuai dengan 
perkembangan kondisi pasien atau pendokumentasian harus akurat. Pendokumentasian asuhan keperawatan merupakan bukti dari pelaksanaan keperawatan yang menggunakan metode pendekatan proses keperawatan dan catatan tentang tanggapan atau respon pasien terhadap tindakan medis, tindakan keperawatan, atau reaksi pasien terhadap penyakit. Pendokumentasian keperawatan juga merupakan informasi tertulis yang akan menjadi dasar penjelasan tentang pasien bagi tim kesehatan atau mereka yang berkepentingan.

\section{REFERENSI}

1. Aldi Anggara Maulana.2015. Hubungan Beban Kerja Perawat Dengan Pelaksanaan Pendokumentasian Asuhan Keperawatan Di Ruang Teratai Rumah Sakit Umum Daerah Ciamis. Skripsi. Program Studi S-1 Keperawatan Sekolah Tinggi Ilmu Kesehatan Muhammadiyah Ciamis.

2. Arizal,dkk.2019. Analisis Rencana Penerapan Sistem Informasi Dalam Pendokumentasian Asuhan Keperawatan Di Rumah Sakit Universitas Tanjungpura. BIMIKI.Vol: 7(2). 19-29.

3. Dunggio,Abdul Rivai Saleh,dkk.2016. Hubungan Pengetahuan dan Motivasi Perawat Dengan Pendokumentasian Asuhan Keperawatan Di Ruang Rawat Inap Rumah Sakit Umum Daerah Tulehu. Global Health Science. Vol: 1(4). 179-195.

4. Ginting,Magdalena, Junita Romaito Sinaga.2019. Hubungan Pelaksana Supervisi Kepala Ruang Dengan Pendokumentasian Asuhan Keperawatan Di Rumah Sakit Martha Friska Pulo Brayan. Jurnal Darma Agung Husada. Vol: V(1). 32-37.

5. Muhaeriwati,Titiek,dkk.2018. Hubungan Konsistensi Budaya Organisasi Dengan Kelengkapan Dokumentasi Keperawatan : Manajemen Nyeri Di Rumah Sakit. Journal Educational of Nursing (JEN). Vol: 1(1). 58-72.

6. Niken Pradipta Sumilat.2017. Standar Pendokumentasian Asuhan Keperawatan di BLUD RSUD BAUBAU. Skripsi. Fakultas Kedokteran dan Ilmu Kesehatan Universitas Islam Negeri Alauddin Makassar.

7. Potter, P.A. dan Perry,A.G.2013. Fundamental of Nursing. Right edition,Mosby : Evolve elsevier Haris (2014).

8. Saputra,Candra, Yulastri Arif, Fitra Yeni.2019. Faktor Yang Berhubungan Dengan Kualitas dan Kelengkapan Dokumentasi Keperawatan. Jurnal Ilmiah Permas : Jurnal Ilmiah STIKES Kendal. Vol: 9(3). 187-196. 
9. Simamora, R.(2009). Dokumentasi Proses Keperawatan.

10. Simamora, R.H., Purba,J.M., Bukit, E. K., \& Nurbaiti, N. (2019). Penguatan Peran Perawat Dalam Pelaksanaan Asuhan Keperawatan Melalui Pelatihan Layanan Prima. JPPM (Jurnal Pengabdian Dan Pemberdayaan Masyarakat), 3(1), 25-31.

11. Yanti, Retyaningsih Ida, Bambang Edi Warsito.2013. Hubungan Karakteristik Perawat, Motivasi, dan Supervisi dengan Kualitas Dokumentasi proses Asuhan Keperawatan. Jurnal Management Keperawatan. Vol: 1(2). 107-114.

12. Yusuf, Muhammad.2013. Hubungan Manajemen Waktu Perawat Pelaksana Dengan Pendokumentasian Asuhan Keperawatan Di Ruang Rawat Inap Kelas III Rumah Sakit Umum Daerah DR.ZAINOEL ABIDIN Tahun 2013. Jurnal Ilmu Kesehatan. Vol: 1(1). 76-84. 